\title{
A PCR assay and PCR-restriction fragment length polymorphism combination identifying the 3 primary Mycoplasma species causing mastitis
}

\author{
S. Boonyayatra, ${ }^{*}$ L. K. Fox,${ }^{\star 1}$ T. E. Besser, $†$ A. Sawant, $†$ J. M. Gay, ${ }^{\star}$ and Z. Raviv \\ ${ }^{*}$ Department of Veterinary Clinical Sciences, and \\ †Department of Veterinary Microbiology and Pathology, College of Veterinary Medicine, Washington State University, Pullman 99164 \\ $\ddagger$ Department of Veterinary Preventive Medicine, The Ohio State University, Columbus 43210
}

\begin{abstract}
The focus of the current research was to develop real-time PCR assays with improved sensitivity and the capacity to simultaneously speciate the 3 most common mycoplasma mastitis agents: Mycoplasma bovis, Mycoplasma californicum, and Mycoplasma bovigenitalium. Real-time PCR was chosen because it provides rapid results. Partial 16S rRNA gene sequencing was used as the gold standard for evaluating candidate real-time PCR assays. To ascertain the real-time PCR assay specificity, reference strains of Mycoplasma species, Acholeplasma axanthum, and common gram-positive and gram-negative mastitis pathogens were tested. No cross-reactions were observed. Mycoplasma spp. isolated from bovine milk samples $(\mathrm{n}=228)$ and other organ sites $(n=40)$ were tested by the real-time PCR assays and the partial $16 \mathrm{~S}$ rRNA gene sequencing assay. Overall accuracy of this novel real-time PCR was $98.51 \%$; 4 of 228 isolates identified as $M$. bovis by the partial 16S rRNA gene sequencing assay were identified as both $M$. bovis and $M$. californicum by real-time PCR. Subsequent amplicon sequencing suggested the presence of both $M$. bovis and $M$. californicum in these 4 samples. Using a cycle threshold of 37 , the detection limits for real-time PCR were 10 copies of DNA template for both $M$. bovis and M. bovigenitalium, and 1 copy for M. californicum. This real-time PCR assay is a diagnostic technique that may be used as a screening tool or as a confirmation test for mycoplasma mastitis. Key words: Mycoplasma species, mastitis, intramammary infection, real-time PCR
\end{abstract}

\section{INTRODUCTION}

Mycoplasma species were first recognized as a cause of contagious mastitis in dairy cattle in the United States in 1961 (Hale et al., 1962). Since then, mycoplasma

Received May 12, 2011.

Accepted September 12, 2011

${ }^{1}$ Corresponding author: fox@wsu.edu mastitis has been reported throughout the country and in many regions of the world (Fox et al., 2005). Mycoplasma spp. are categorized as contagious mastitis pathogens (Fox and Gay, 1993), and mycoplasma mastitis appears to be an emerging problem in the United States, with approximately 10 to $20 \%$ of large $(>500$ cows) dairy herds affected by this agent (USDA, 2008). Because of the difficulty in culturing the pathogen, it is likely that mycoplasma mastitis is under-reported (Nicholas et al., 2007). Moreover, Nicholas et al. (2007) indicate that the cost of the disease has been estimated to exceed $\$ 100$ million annually in the United States.

Mycoplasma bovis is the most common Mycoplasma species associated with mastitis and accounts for 49 to $60 \%$ of isolates (Jasper, 1979; Kirk et al., 1997). Mycoplasma californicum and Mycoplasma bovigenitalium are frequently reported as being associated with mastitis in dairy cows and appear to be the next most common causes of mycoplasma mastitis (Jasper, 1979; Kirk et al., 1997).

The slow growth and fastidious nutritional requirements of Mycoplasma spp. in vitro impede identification of this genus. Although culture is the primary method for mycoplasma identification, culture cannot distinguish between pathogenic and nonpathogenic species and requires up to $10 \mathrm{~d}$ to reach a definitive culture diagnosis (Hogan et al., 1999). Highly specific and sensitive PCR techniques can overcome these problems (Pinnow et al., 2001). Currently, nested PCR followed by RFLP analysis is used to identify suspected $\mathrm{Myco-}$ plasma spp. isolates (Tang et al., 2000). Although this technique is promising for identification of Mycoplasma species directly from biological samples, it requires 2 steps of PCR and a long period of incubation for enzyme digestion, requiring approximately 18 to $30 \mathrm{~h}$ to complete.

Real-time PCR techniques might overcome the difficulties associated with the in vitro culture of Mycoplasma spp. and reduce the time needed for speciation by conventional PCR. Real-time PCR methods have been available for more than a decade (Heid et al., 1996) and facilitate the screening of large numbers of 
samples within a few hours with excellent sensitivity and specificity. Fluorescence detection of specific PCR products and accumulation of this signal for each PCR cycle on a real-time basis enable quantification of template DNA (Leutenegger, 2001). Real-time PCR with fluorogenic probes (TaqMan, Qiagen, Valencia, CA) increases the specificity of real-time PCR assays because only a specific amplicon target sequence is recognized.

The purpose of this study was to develop 3 real-time PCR assays capable of detecting the 3 most common mycoplasma mastitis agents, M. bovis, M. californicum, and $M$. bovigenitalium. To validate these newly developed real-time PCR assays, the conventional PCR described by Tang et al. (2000) was also performed on the same samples and results were compared using $16 \mathrm{~S}$ rRNA gene partial sequencing as a gold standard basis of c,omparison.

\section{MATERIALS AND METHODS}

\section{Organisms}

A set of 13 representative Mollicutes and 15 other eubacterial species obtained from the American Type Culture Collection (ATCC, Manassas, VA) were used to determine the analytical specificity of the candidate real-time PCR assays (Table 1). A set of 268 isolates from bovine sources, primarily milk samples $(\mathrm{n}=228)$ and samples from other organ sites $(\mathrm{n}=40)$, isolated on modified Hayflick's agar, was used to determine the analytical sensitivity of candidate PCR reactions. Samples from other organ sites were obtained by using a polyester-tipped swab moistened with mycoplasma enrichment medium and swabbed over the mucosal surface of the tissues (Biddle et al., 2005). Organ systems included the eye, respiratory, and urogenital systems. Swab samples were also collected from the outer ear, buccal cavity, and rectum. To ensure purity, a filtration-cloning technique as described by Tully (1983) was performed on all Mollicute isolates. All isolates were cultured in pleuropneumonia-like organism (PPLO) broth (BBL, Franklin Lakes, NJ), in a $10 \% \mathrm{CO}_{2}$ environment for $4 \mathrm{~d}$. Glycerol ( $30 \% \mathrm{vol} / \mathrm{vol})$ was added to cultured broth before storage at $-85^{\circ} \mathrm{C}$ until use.

\section{Primers and Probes Designed for M. bovis, M. californicum, and $M$. bovigenitalium}

Primers and probes were designed using the Qiagen online tool (http://www1.qiagen.com/products/pcr/ quantitect/customassays.aspx; Qiagen, Valencia, CA). Three different housekeeping genes, fusA encoding for elongation factor $\mathrm{G}$, rpoB encoding for RNA polymerase $\beta$ subunit, and 16S-23S rRNA intergenic spacer region
(IGS) were selected for $M$. bovis, M. californicum, and $M$. bovigenitalium. Primers and probes were tested for interactions using the online Oligo Analysis tool (http://www.operon.com/technical/toolkit.aspx). The sequences were tested for their specificity by searching against the GenBank database using the Basic Local Alignment Search Tool (BLAST; Altschul et al., 1990). The sequences of primers and probes are shown in Table 2.

\section{Genomic DNA Extraction for PCR}

Using PureLink Genomic DNA Kits (Invitrogen, Carlsbad, CA), a silica-based column purification method, gram-negative bacterial genomic DNA extraction was performed on all Mollicute and gram-negative cultures according to the manufacturer's instructions. For gram-positive bacteria, genomic DNA was extracted according to the protocol described by Pitcher et al. (1989). All genomic DNA extracts were frozen at $-80^{\circ} \mathrm{C}$ until further use.

\section{Real-Time PCR}

The PCR reaction was initiated by combining 5 $\mu \mathrm{L}$ of the extracted DNA with $12.5 \mu \mathrm{L}$ of $2 \times$ Master Mix: HotStart Taq DNA polymerase, dNTP mix, ROX passive reference dye, and QuantiTect Probe real-timePCR buffer [containing Tris-Cl, $\mathrm{KCl},\left(\mathrm{NH}_{4}\right)_{2} \mathrm{SO}_{4}, 8 \mathrm{mM}$ $\mathrm{MgCl}_{2}, \mathrm{pH}$ 8.7], $10 \mathrm{pmol}$ of each primer, and 5 pmol of probe according to the QuantiTect Probe PCR kit (Qiagen) instructions. All real-time PCR assays were performed on a Step One Plus (Applied Biosystems, Foster City, CA) real-time PCR instrument. The thermal cycling protocol included 15 min of predenaturation at $95^{\circ} \mathrm{C}, 45$ cycles of $15 \mathrm{~s}$ of denaturation at $94^{\circ} \mathrm{C}$, and $60 \mathrm{~s}$ of annealing at $60^{\circ} \mathrm{C}$. Based on a cycle threshold $\left(\mathbf{C}_{\mathbf{T}}\right)$ of 37 , each reaction was classified as positive or negative for a target (Bustin, 2004).

\section{Quantitative Testing of the Real-Time PCR Assays}

To establish the quantitative ability of each real-time PCR assay, a standard curve was generated. Target sequences in fus $A, r p o B$, and ITS genes were cloned into pIDTSMART-AMP plasmids (Integrated DNA Technologies, Coralville, IA). All plasmids were diluted to concentrations of $20,000,2,000,200,20,2$, and 0.2 copies of DNA template $/ \mu \mathrm{L}$. Five microliters of each dilution was combined with primers, probes, and 12.5 $\mu \mathrm{L}$ of $2 \times$ Master Mix as described previously. To generate standard curves for $M$.bovis, M. bovigenitalium, and M. californicum real-time PCR assays, each dilution of each target DNA was tested in triplicate. 
Table 1. Mycoplasma species and other bacterial species tested for specificity of the novel real-time PCR assays ${ }^{1}$

Real-time PCR

\begin{tabular}{|c|c|c|c|c|c|}
\hline Organism & Origin of isolates & Source $^{2}$ & M. bovis & M. californicum & M. bovigenitalium \\
\hline Mycoplasma bovis & Bovine mastitic milk & ATCC 25025 & + & - & - \\
\hline M. bovis & Bovine mastitic milk & ATCC 25523 & + & - & - \\
\hline M. bovis & Bovine mastitic milk & CU 22253 & + & - & - \\
\hline Mycoplasma californicum & Bovine mastitic milk & ATCC 33461 & - & + & - \\
\hline Mycoplasma bovigenitalium & Bovine genital tract & ATCC 14173 & - & - & + \\
\hline Mycoplasma alkalescens & Bovine nasal cavity & ATCC 29103 & - & - & - \\
\hline M. alkalescens & Bovine mastitic milk & CU 21146 & - & - & - \\
\hline Mycoplasma agalactiae & Mastitic goat milk & ATCC 35890 & - & - & - \\
\hline Mycoplasma arginini & Lung of sheep with pneumonia & ATCC 23243 & - & - & - \\
\hline Mycoplasma bovirhinis & Bovine respiratory tract & ATCC 27748 & - & - & - \\
\hline Mycoplasma leachii sp. nov. & Arthritic joint of a calf & IOM N29 Leach strains & - & - & - \\
\hline Mycoplasma ovipneumonia & Ovine respiratory tract & ATCC 29419 & - & - & - \\
\hline Acholeplasma axanthum & Murine leukemia tissue culture & ATCC 25176 & - & - & - \\
\hline Escherichia coli & Clinical isolates & ATCC 25922 & - & - & - \\
\hline Staphylococcus simulans & Human & ATCC 11631 & - & - & - \\
\hline Staphylococcus epidermidis & Human & ATCC 12228 & - & - & - \\
\hline Staph. epidermidis & Human (catheter sepsis) & ATCC 35984 & - & - & - \\
\hline Staphylococcus equorum & Horse skin & ATCC 43958 & - & - & - \\
\hline Staphylococcus hemolyticus & Human skin & ATCC 29970 & - & - & - \\
\hline Staphylococcus gallinarum & Chicken nares & ATCC 35539 & - & - & - \\
\hline Staphylococcus hyicus & Pig with exudative epidermitis & ATCC 11249 & - & - & - \\
\hline Staphylococcus intermedius & Pigeon nares & ATCC 29663 & - & - & - \\
\hline Staphylococcus caprae & Goat milk & ATCC 35538 & - & - & - \\
\hline Staphylococcus capitis & Human & ATCC 35661 & - & - & - \\
\hline Staphylococcus chromogenes & Pig skin & ATCC 43764 & - & - & - \\
\hline Staphylococcus aureus & Bovine mastitic milk & ATCC 29740 & - & - & - \\
\hline Streptococcus uberis & Bovine udder infection & ATCC 27958 & - & - & - \\
\hline Streptococcus dysgalactiae & Bovine udder infection & ATCC 27957 & - & - & - \\
\hline
\end{tabular}

${ }^{1}$ Isolates with a + sign were positively identified by real-time PCR as that species and those with a - sign were not identified, using a cycle threshold value of 37 as the threshold of determination.

${ }^{2}$ ATCC $=$ American Type Culture Collection (Manassas, VA); CU = Cornell University (Ithaca, NY); IOM = International Organization of Mycoplasmology (West Lafayette, IN).

\section{Detection Limit of Real-Time PCR Assays in Milk Samples}

To determine the detection limit of each real-time PCR assay, 10-fold serial dilutions of 2 strains of $M$. bovis, $M$. californicum, and $M$. bovigenitalium were made in Mycoplasma-free milk. Two milliliters of inoculated milk was centrifuged at $14,000 \times g$ for $3 \mathrm{~min}$. The supernatant was discarded and genomic DNA was extracted from milk cell pellet using PureLink Genomic DNA Kit (Invitrogen). One hundred microliters of the same inoculated milk was spread on Modified Hayflick's media, and plates were incubated for 7 to $10 \mathrm{~d}$ before enumeration of mycoplasma colonies.

\section{PCR-RFLP}

Adapted from Tang et al. (2000), a one-step PCR followed by RFLP was performed in a total volume of 50 $\mu \mathrm{L}$ containing $1 \times$ PCR buffer $(20 \mathrm{~m} M$ Tris- $\mathrm{HCl}, 2 \mathrm{mM}$ $\mathrm{MgCl}_{2}$, and $\left.50 \mathrm{mM} \mathrm{KCl} ; \mathrm{pH} 8.4\right), 50 \mu \mathrm{mol}$ of each of deoxynucleoside triphosphates (dNTP), $20 \mathrm{pmol}$ of each primer, and $1 \mathrm{U}$ of Taq DNA polymerase (Invitrogen).
A set of primers including F2, R2, and R34 was used to amplify the 16S-23S rRNA intergenic spacer regions of Mycoplasma and Acholeplasma. Sequences and targets of these primers are shown in Table 2. Five microliters of DNA extract was used as a template and added to $45 \mu \mathrm{L}$ of reaction mixture. The thermal cycling protocol was programmed as described previously (Tang et al., 2000) and products were digested by a restriction enzyme, Ase1. Products were electrophoresed on a $2 \%$ agarose gel and patterns of DNA fragments were visualized by UV fluorescence.

\section{S rRNA Gene Partial Sequencing}

A 16S rRNA gene region of approximately 1,500 bp was amplified using a universal primer pair, $\mathrm{pH}$ and pA, as listed in Table 2 (Stakenborg et al., 2005). The $50-\mu \mathrm{L}$ PCR reaction mixture included $3 \mathrm{U}$ of Taq DNA polymerase (Invitrogen), $1 \times$ PCR buffer $(20 \mathrm{~m} M$ Tris-

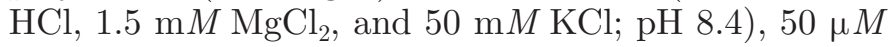
of each dNTP, $10 \mathrm{pmol}$ of each primer, and $1 \mu \mathrm{L}$ of the genomic DNA as template. The thermal cycling protocol was programmed as described previously (Staken- 


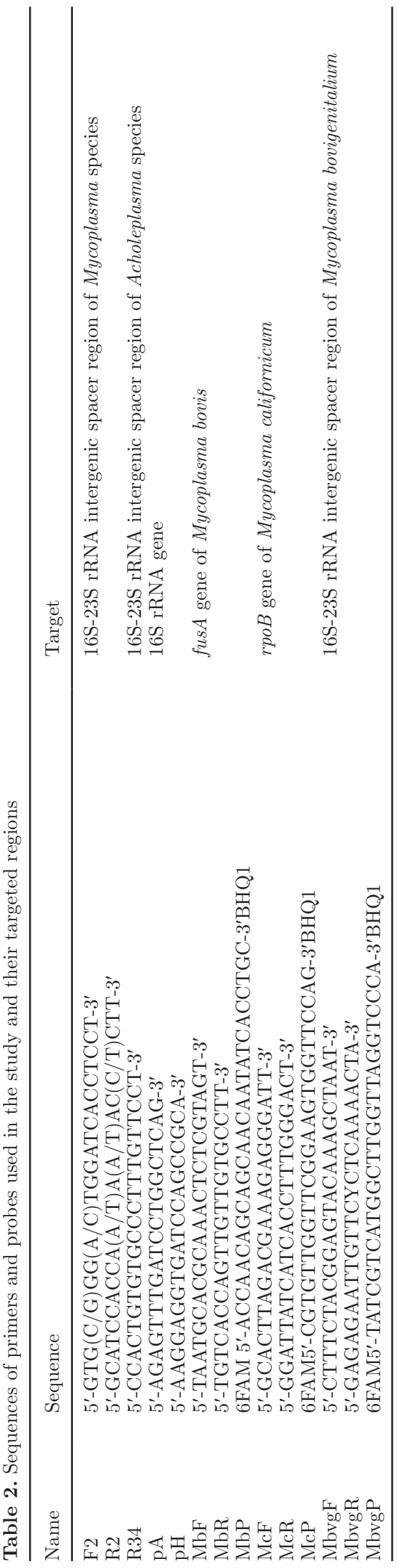

borg et al., 2005). The PCR products were sequenced using primer pA (Macrogen Corp., Rockville, MD) and the sequences were compared with the GenBank database using BLAST (Altschul et al., 1990). A hit was identified as the species giving the highest value but at least $98 \%$ identity.

\section{Statistical Analysis}

All isolate assays were performed in duplicate. If the replicates did not agree, a third replicate was performed. $\mathrm{A}_{\mathrm{T}}$ of 37 was used to define the presence or absence of a Mycoplasma species. Identification was regarded as definitive identification by real-time PCR if both replicates had $\mathrm{C}_{\mathrm{T}}<37$.

For PCR-RFLP, identification was regarded as definitive if the DNA fragment patterns were identical. Results are presented as percentage agreement with 16S rRNA gene partial sequencing where the denominator was the number of isolates identified as $M$. bovis, M. californicum, or M. bovigenitalium by the $16 \mathrm{~S}$ rRNA gene partial sequencing technique and the numerator was the number of matched isolates identified as $M$. bovis, M. californicum, or $M$. bovigenitalium by each PCR technique. The percentage accuracy is the proportion of field samples with Mollicutes that were classified correctly, with the denominator being the total number of field samples and the numerator being the number of samples in complete agreement.

\section{RESULTS}

\section{Mycoplasma Isolates Identified by 165 rRNA Gene Partial Sequencing}

Based on the identification using 16S rRNA gene partial sequencing, of the 268 isolates from milk and other organ sites, 228 (85.07\%), $22(8.21 \%)$, and 5 (1.87\%) were identified as M. bovis, M. californicum, and $M$. bovigenitalium, respectively. The distribution of Mycoplasma and Acholeplasma isolates is listed in Table 3.

\section{Identification of M. bovis, M. californicum, and M. bovigenitalium Using PCR-RFLP}

The patterns of amplicons before and after Ase 1 digestion of M. bovis, M. californicum, and M. bovigenitalium are illustrated in Figures $1 \mathrm{a}$ and $1 \mathrm{~b}$. The sizes of digested amplicon for $M$. bovis were 140, 125, and $115 \mathrm{bp}$ and for M. bovigenitalium 265 and $115 \mathrm{bp}$. The amplicon of $M$. californicum (370 bp) could not be cut by Ase1 (Figure 1b). All M. bovis isolates $(228 / 228)$ and all M. californicum isolates $(22 / 22)$ were correctly 
Table 3. Distribution of isolates of Mycoplasma spp. and Acholeplasma spp. as identified by 16S rRNA partial sequencing

\begin{tabular}{|c|c|c|c|c|}
\hline $\begin{array}{l}\text { Species identification using } \\
\text { 16S rRNA partial sequencing }\end{array}$ & $\begin{array}{l}\text { No. of isolates } \\
\text { from milk samples }\end{array}$ & $\begin{array}{l}\text { No. of isolates } \\
\text { from body sites } \\
\text { and other organs }\end{array}$ & $\begin{array}{l}\text { No. of } \\
\text { reference strains }\end{array}$ & Total \\
\hline Mycoplasma bovis & 212 & 16 & 3 & 231 \\
\hline Mycoplasma californicum & 11 & 11 & 1 & 23 \\
\hline Mycoplasma bovigenitalium & 2 & 3 & 1 & 6 \\
\hline Acholeplasma axanthum & 0 & 1 & 1 & 2 \\
\hline Mycoplasma alkalescens & 2 & 0 & 2 & 4 \\
\hline Mycoplasma arginini & 1 & 2 & 1 & 4 \\
\hline Mycoplasma yeatsii & 0 & 2 & 0 & 2 \\
\hline Mycoplasma cottewii & 0 & 1 & 0 & 1 \\
\hline Mycoplasma bovirhinis & 0 & 0 & 1 & 1 \\
\hline Mycoplasma felis & 0 & 1 & 0 & 1 \\
\hline Mycoplasma leachii (bovine serogroup 7) & 0 & 0 & 1 & 1 \\
\hline Mycoplasma aqalactiae $^{2}$ & 0 & 3 & 1 & 4 \\
\hline Mycoplasma ovipneumonia & 0 & 0 & 1 & 1 \\
\hline Total & 228 & 40 & 13 & 281 \\
\hline
\end{tabular}

${ }^{1}$ Two hundred twenty-one isolates were from milk samples collected from cows with clinical mastitis and 7 isolates were from bulk tank milk samples.

${ }^{2}$ Three $M$. agalactiae isolates were laboratory strains of unknown origin.

identified as shown in Table 4. None of the field strains of $M$. bovigenitalium were correctly identified by PCRRFLP. Amplicons of $2 M$. bovigenitalium isolates were not digested by Ase1, resulting in an electrophoretic pattern similar to those of $M$. californicum isolates as shown in Figure 2, lanes 2 and 4 . These 2 isolates were misidentified by PCR-RFLP and thus would be considered as $M$. bovigenitalium false-negative results. Because these isolates were identified as $M$. californicum by PCR-RFLP, they would be considered as falsepositive $M$. californicum results. The other 3 isolates identified as $M$. bovigenitalium by the $16 \mathrm{~S}$ rRNA gene partial sequencing were not identified by PCR-RLFP (Figure 2, lanes 3, 5, and 6). Given that all 5 field isolates of $M$. bovigenitalium were misidentified, the test accuracy was $98.13 \%$ (263 of 268 samples accurately identified).

\section{Test Specificity and Detection Limit of Real-Time PCR Assays}

Genomic DNA of 15 eubacterial species and 13 representative Mollicutes were tested to define analytical specificity (Table 4). All M. bovis, M. bovigenitalium, and $M$. californicum strains produced the expected amplification signals, and log-linear dependences of $\mathrm{C}_{\mathrm{T}}$ value on mycoplasma copy number were observed (Figures 3, 4, and 5). No specific products from other Mycoplasma species and eubacterial species were detected, and cross-reactivity was not observed.

The detection limit of all 3 assays was as low as 1 to 10 copies of targeted DNA (Figures 3-5). A $\mathrm{C}_{\mathrm{T}}$ of 37 is the detection limit of 1 copy of $M$. californicum and approximately 10 copies of $M$. bovis and M. bovigenitalium. Moreover, the geometric means of the detection limits of the genomic DNA extracted from milk were $10 \pm 0(\mathrm{SE}) \mathrm{cfu} / \mathrm{mL}\left(\mathrm{C}_{\mathrm{T}}=39.5 \pm 0.6\right), 22.4 \pm 20 \mathrm{cfu} /$ $\mathrm{mL}\left(\mathrm{C}_{\mathrm{T}}=41.7 \pm 3.3\right)$, and $20 \pm 0 \mathrm{cfu} / \mathrm{mL}\left(\mathrm{C}_{\mathrm{T}}=33.7\right.$ \pm 0.1 ) for M. bovis, M. californicum, and M. bovigenitalium real-time PCR assays, respectively.

\section{Identification of M. bovis, M. californicum, and M. bovigenitalium Using Real-Time PCR Assays}

For 228 isolates of M. bovis, 22 of M. californicum, and 5 of $M$. bovigenitalium, the real-time PCR assay and the $16 \mathrm{~S}$ rRNA gene partial sequencing were in $100 \%$ agreement (Table 4). However, 4 isolates that were identified by the $16 \mathrm{~S}$ rRNA gene partial sequencing as $M$. bovis were identified as both $M$. bovis and $M$. californicum by real-time PCR. Thus, the accuracy of the real-time PCR test relative to the $16 \mathrm{~S}$ rRNA gene partial sequencing technique was $98.51 \%$ (264 of 268 samples were correctly identified). To investigate the possibility of cross amplification between the 2 species by the real-time PCR, those 4 isolates were amplified using the primers for M. californicum. Amplicons obtained from those 4 isolates were sequenced and searched for similarity against GenBank database. All 4 amplicons matched $100 \%$ with the target sequence of $M$. californicum, suggesting that both $M$. bovis and M. californicum were present and that the original $16 \mathrm{~S}$ rRNA gene partial sequence analysis did not detect $M$. californicum.

\section{DISCUSSION}

The goal of the current research was to develop realtime PCR assays to detect the 3 most common mycoplasma mastitis agents: M. bovis, M. californicum, and 
A

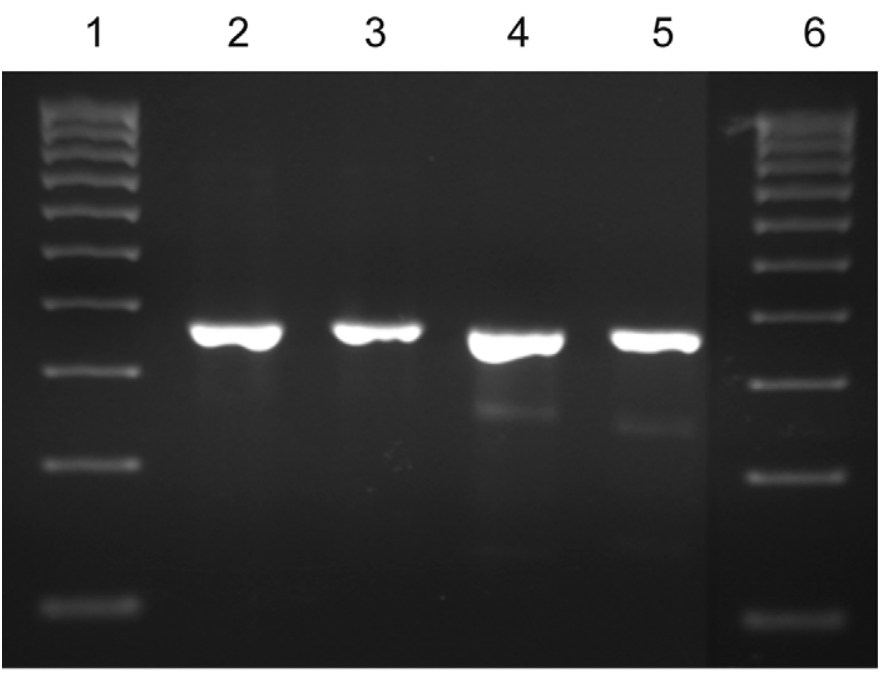

B

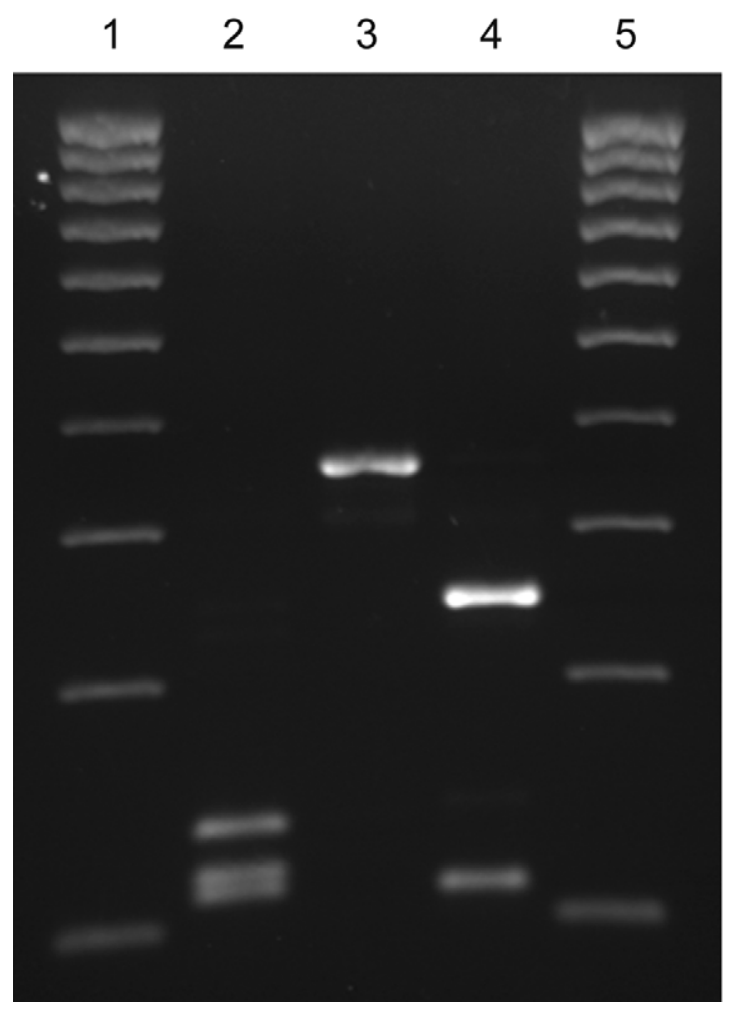

Figure 1. Electrophoretic gel of amplicons before digestion (A) and after digestion by Ase 1 (B). (A) Lanes 1 and $6=100$-bp molecular ladder, lane $2=$ Mycoplasma bovis ATCC 25025, lane $3=M$. bovis ATCC 25523, lane $4=$ Mycoplasma californicum ATCC 33461, lane $5=$ Mycoplasma bovigenitalium ATCC 14173. (B) Lanes 1 and $5=$ 100-bp molecular ladder, lane $2=M$. bovis ATCC 25025, lane $3=M$. californicum ATCC 33461, lane $4=M$. bovigenitalium ATCC 14173. ATCC $=$ American Type Culture Collection .
M. bovigenitalium. All 3 assays correctly detected the specific target regions selected without cross amplification with other Mycoplasma spp. or other bacteria. The real-time PCR developed yielded results that were in $100 \%$ agreement with identification by the gold standard test, $16 \mathrm{~S}$ rRNA gene partial sequence analysis. Relative test accuracy was $98.51 \%$, because 264 of the 268 samples were classified similarly by both assays. The 4 samples that appeared to be misclassified might have been more accurately classified by the real-time PCR assay compared with the $16 \mathrm{~S}$ rRNA gene partial sequence analysis. Further analysis of the real-time PCR amplicons suggested that in these 4 samples, both $M$. bovis and M. californicum were present. Isolates were obtained from milk and other body sites to determine whether strains that might colonize or infect one organ system might be significantly different from those at other sites, and thus would not be correctly identified with the assay system developed. The $100 \%$ agreement between the real-time PCR and the $16 \mathrm{~S}$ rRNA gene partial sequence assays indicated that source of isolate did not affect correct identification.

Results described herein verify success in establishing a 16S rRNA gene partial sequencing assay to detect 3 common mycoplasma mastitis pathogens accurately and rapidly. Species identification of mycoplasma mastitis agents is generally done by serological or PCR assays (González and Wilson, 2003). Time needed to speciate Mycoplasma by serology is less than $1 \mathrm{~h}$ (Infante Martinez et al., 1990), much less than PCR, which may require $24 \mathrm{~h}$ (González and Wilson, 2003). However, serological testing is not as sensitive as conventional $\mathrm{PCR}$, the former detecting $5,000 \mathrm{cfu} / \mathrm{mL}$ and the latter approximately $100 \mathrm{cfu} / \mathrm{mL}$ or less (Hirose et al., 2001; Pinnow et al., 2001; Infante et al., 2002). The described real-time PCR assay procedure can detect 10 to $30 \mathrm{cfu/}$ $\mathrm{mL}$ Mycoplasma; such a test was made using milk as a diluent in an effort to determine if the assay could later be developed to identify mycoplasma mastitis agents directly in milk. Time to completion of the assay was approximately $4 \mathrm{~h}$. Another advantage is that it detects the most prevalent species that cause Mycoplasma mastitis. The 3 most prevalent species of mycoplasma mastitis agents are M. bovis, M. californicum, and $M$. bovigenitalium (Jasper, 1980; Kirk and Lauerrman, 1994). Our findings from cows with clinical mastitis sampled in Washington support that conclusion, 93\% (212/228) being $M$. bovis, 5\% (11/228) being $M$. californicum, and $1 \%(2 / 228)$ being $M$. bovigenitalium.

Mycoplasma bovis is regarded as the most pathogenic Mollicute to frequently cause mastitis. (Gonzalez and Wilson, 2003) but M. californicum and M. bovigenitalium are reported as significant causes of IMI (Jasper, 1980; Jurmanová et al., 1983; Mackie et al., 1986; Jack- 
Table 4. Identification of Mycoplasma spp. and Acholeplasma spp. isolates isolated from field samples using PCR-RFLP and real-time PCR ${ }^{1}$

\begin{tabular}{|c|c|c|c|c|c|c|c|c|c|}
\hline \multirow[b]{2}{*}{ Species } & \multirow[b]{2}{*}{ Total } & \multicolumn{4}{|c|}{ PCR-RFLP } & \multicolumn{4}{|c|}{ Real-time PCR } \\
\hline & & M. bovis & M. calif & M. bovigen & $\begin{array}{c}\text { Other } \\
\text { species }\end{array}$ & M. bovis & M. calif & M. bovigen & $\begin{array}{l}\text { Other } \\
\text { species }\end{array}$ \\
\hline Mycoplasma bovis & 228 & 228 & 0 & 0 & 0 & 228 & $4^{2}$ & 0 & 0 \\
\hline Mycoplasma californicum & 22 & 0 & 22 & 0 & 0 & 0 & 22 & 0 & 0 \\
\hline Mycoplasma bovigenitalium & 5 & 0 & 2 & 0 & 3 & 0 & 0 & 5 & 0 \\
\hline Mycoplasma alkalescens & 2 & 0 & 0 & 0 & 2 & 0 & 0 & 0 & 2 \\
\hline Mycoplasma agalactiae & 3 & 0 & 0 & 0 & 3 & 0 & 0 & 0 & 3 \\
\hline Mycoplasma arginini & 3 & 0 & 0 & 0 & 3 & 0 & 0 & 0 & 3 \\
\hline Mycoplasma yeatsii & 2 & 0 & 0 & 0 & 2 & 0 & 0 & 0 & 2 \\
\hline Mycoplasma cottewii & 1 & 0 & 0 & 0 & 1 & 0 & 0 & 0 & 1 \\
\hline Mycoplasma felis & 1 & 0 & 0 & 0 & 1 & 0 & 0 & 0 & 1 \\
\hline Acholeplasma axanthum & 1 & 0 & 0 & 0 & 1 & 0 & 0 & 0 & 1 \\
\hline Total & 268 & 228 & 24 & 0 & 16 & 228 & 26 & 5 & 14 \\
\hline
\end{tabular}

${ }^{1}$ Species identified by $16 \mathrm{~S}$ rRNA partial sequencing. M. calif = Mycoplasma californicum; M. bovigen = Mycoplasma bovigenitalium.

${ }^{2}$ Four field isolates identified by the gold standard as M. bovis were identified as M. bovis and M. californicum by real-time PCR.

son and Boughton, 1991). The inability to identify $M$. californicum and M. bovigenitalium in a mastitic milk sample or to mistake a Mycoplasma as a nonpathogenic Mollicute may lead to excessive transmission of the disease given the contagious nature of these pathogens.

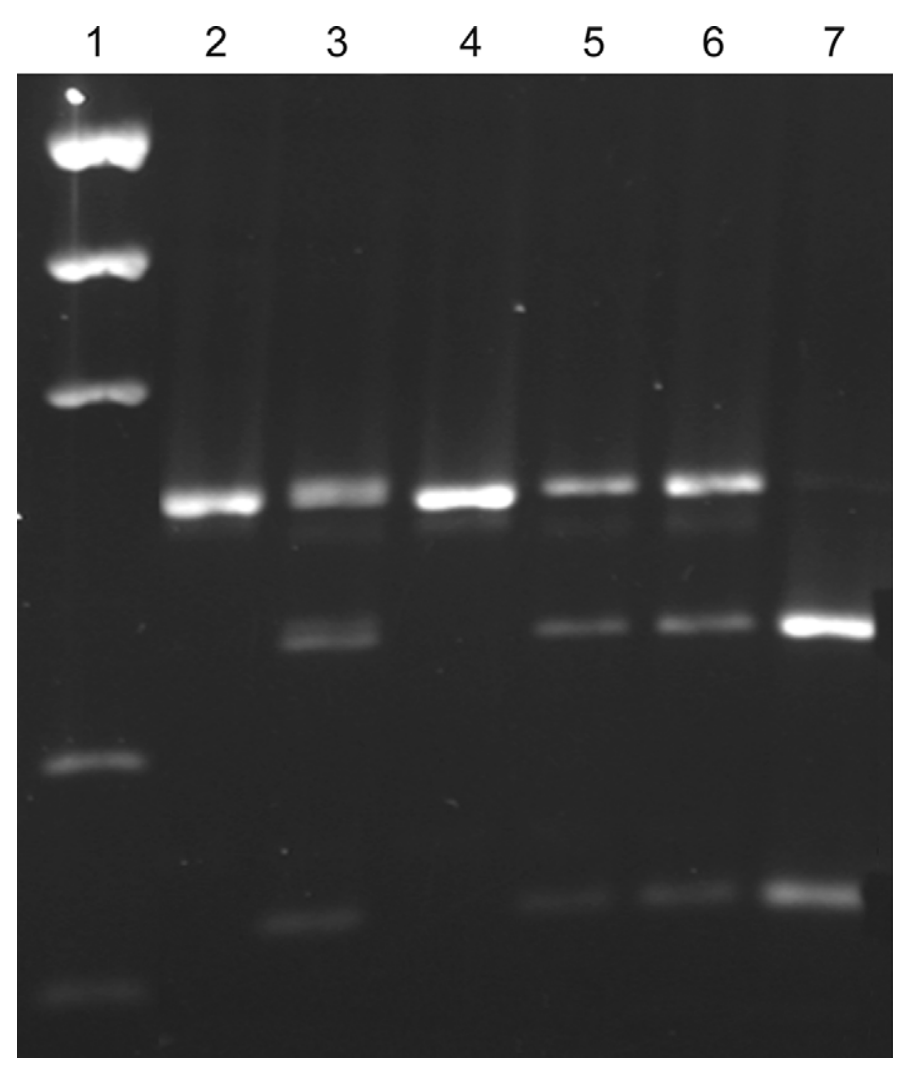

Figure 2. Digested amplicons obtained from 6 Mycoplasma bovigenitalium isolates. Lane $1=$ precision mass molecular ladder (bands from top to bottom represent 1,000, 700, 200, and $100 \mathrm{bp}$ ), lanes 2 to 6 $=$ field isolates of $M$. bovigenitalium, lane $7=M$. bovigenitalium ATCC 14173. ATCC $=$ American Type Culture Collection.
Thus, the development of the described real-time PCR assay technique with its advantages in more timely identification of the common mycoplasma mastitis agents is warranted. The next step is the development of a multiplex system that would work directly in milk.

Several real-time PCR assays have been reported to detect $M$. bovis in many kinds of biological samples. Cai et al. (2005) successfully developed a real-time PCR assay that uses fluorescence resonance energy transfer (FRET) probes to detect $M$. bovis in milk and lung samples. Their system targets a region in $16 \mathrm{~S}$ rRNA gene that has a positive result with both $M$. bovis and Mycoplasma agalactiae. To distinguish between these species, Cai et al. (2005) measured the melting temperature of probes. The detection limits they reported were $550 \mathrm{cfu} / \mathrm{mL}$ of milk. Sachse et al. (2010) reported a novel real-time PCR assay detecting $M$. bovis in nasal and conjunctival swabs and from milk samples. This real-time PCR assay targets the 3 '-terminal region of the $о p p D$ gene encoding for an oligopeptide permease, a member of the ABC-transporter family. Sachse et al. (2010) reported the detection limit of their assay to be $100 \mathrm{cfu} / \mathrm{mL}$ of milk. Recently, Rossetti et al. (2010) developed a real-time PCR assay to detect $M$. bovis from milk lysate. Their assay targets a region in uvrC gene encoding for a part of exinuclease. The detection limit they reported is $2,000 \mathrm{cfu} / \mathrm{mL}$ of milk (Rossetti et al., 2010). Our real-time PCR assay targeted the fusA gene encoding for elongation factor $\mathrm{G}$ of $M$. bovis. The real-time PCR assays detecting $M$. bovis targeting oppD (Sachse et al., 2010), uvrC (Rossetti et al., 2010), and fus $A$ have the advantage that they appear to be free of cross-amplification with $M$. agalactiae. The real-time PCR assay described herein is the first to speciate the 3 Mycoplasma pathogens most commonly associated with mastitis. 


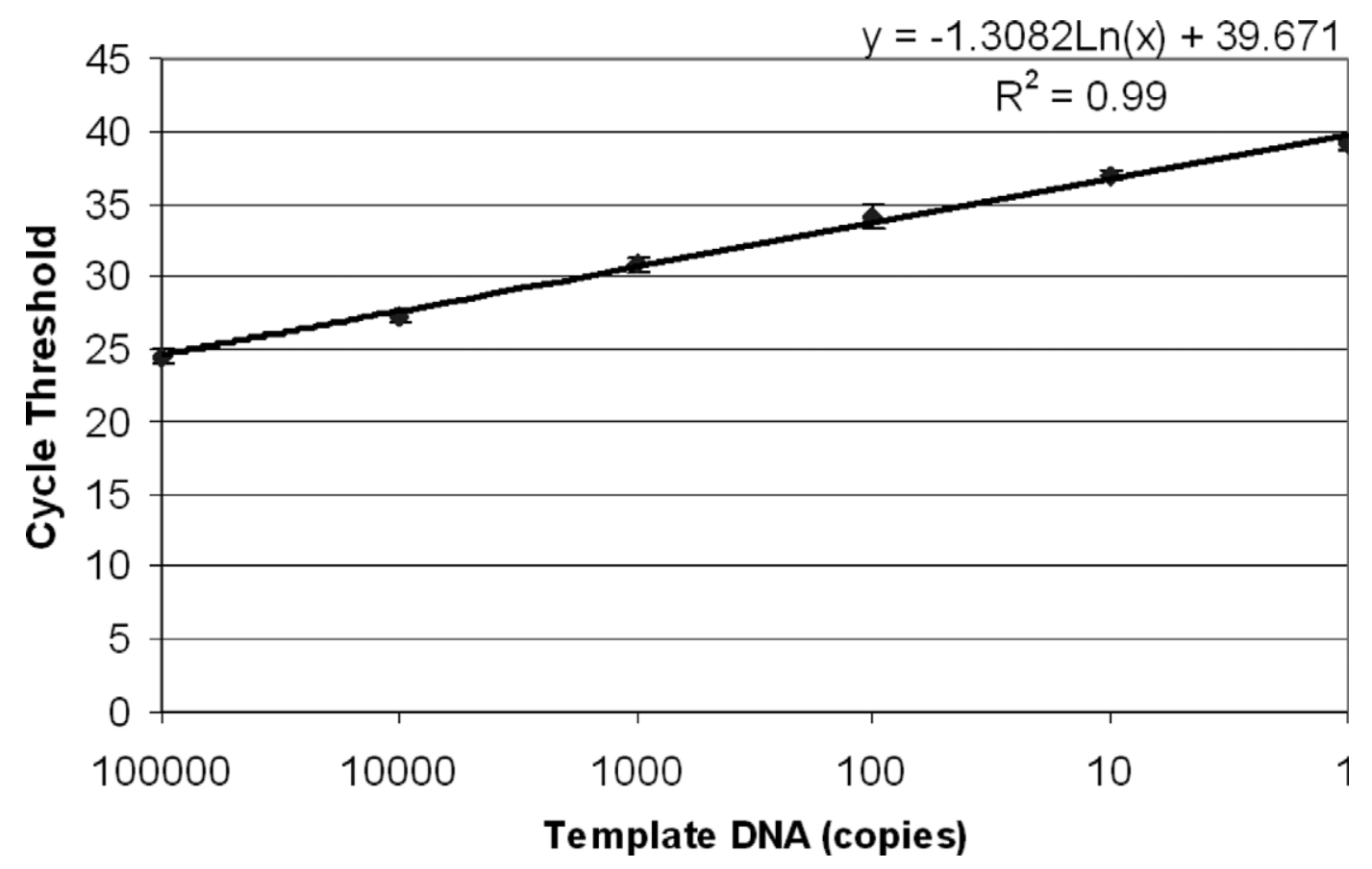

Figure 3. Standard curve of Mycoplasma bovis real-time PCR assay using pIDTSMART-AMP plasmids cloned with the target sequence in fusA gene of $M$. bovis.

Several techniques have been developed to detect Mycoplasma species, primarily for detection of cell culture contamination (Hay et al., 1989; Harasawa et al., 1993). We have applied a PCR-RFLP technique (Tang et al., 2000) to speciate Mycoplasma species in our laboratory. This technique was developed to detect cell culture contamination and heretofore has not been tested with Mycoplasma strains found in cattle.

In this study, we used a cut-off value of $\mathrm{C}_{\mathrm{T}}<37$ to discriminate between detection and nondetection. This

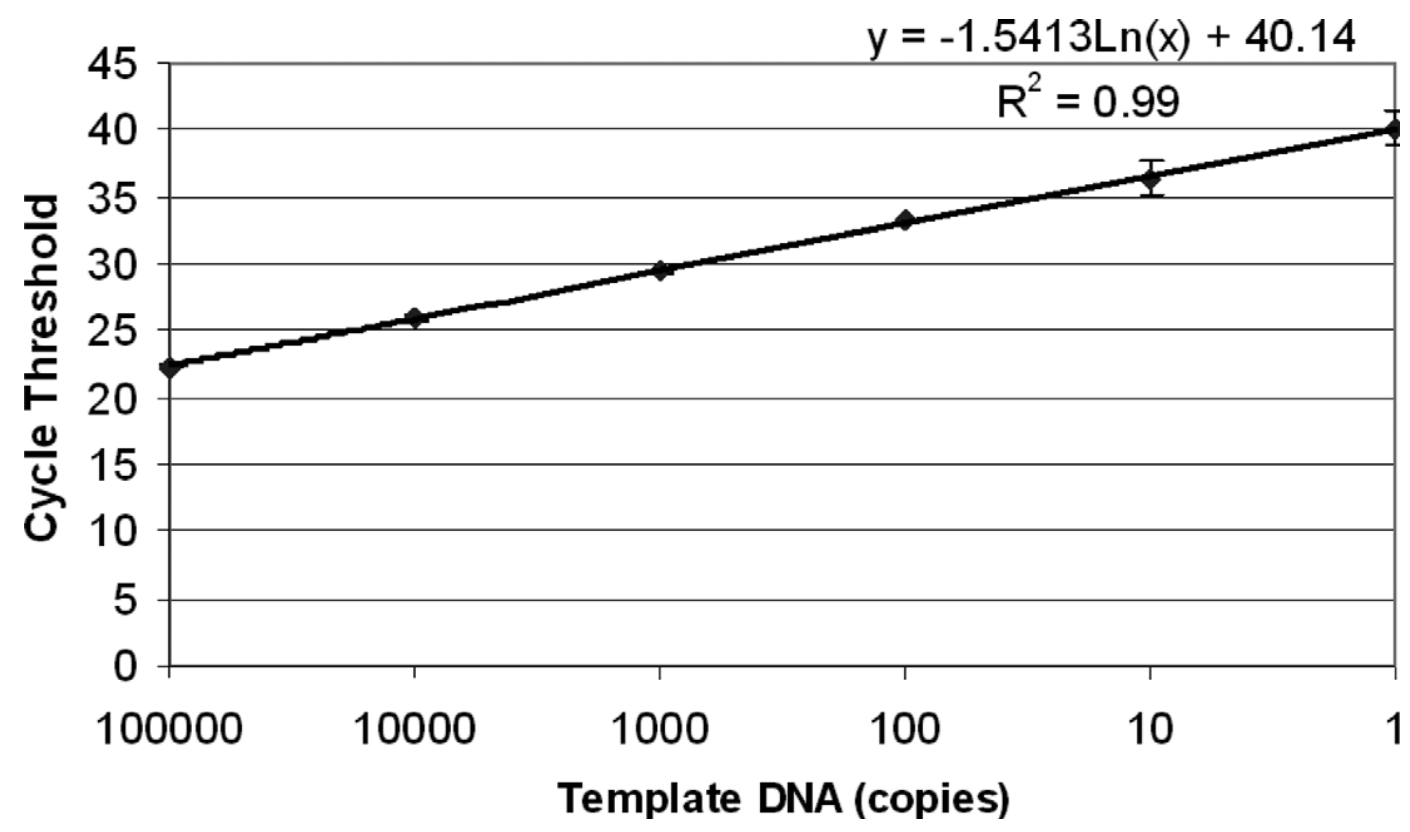

Figure 4. Standard curve of Mycoplasma bovigenitalium real-time PCR assay using pIDTSMART-AMP plasmids cloned with the target sequence in 16S-23S intergenic spacer region of $M$. bovigenitalium. 


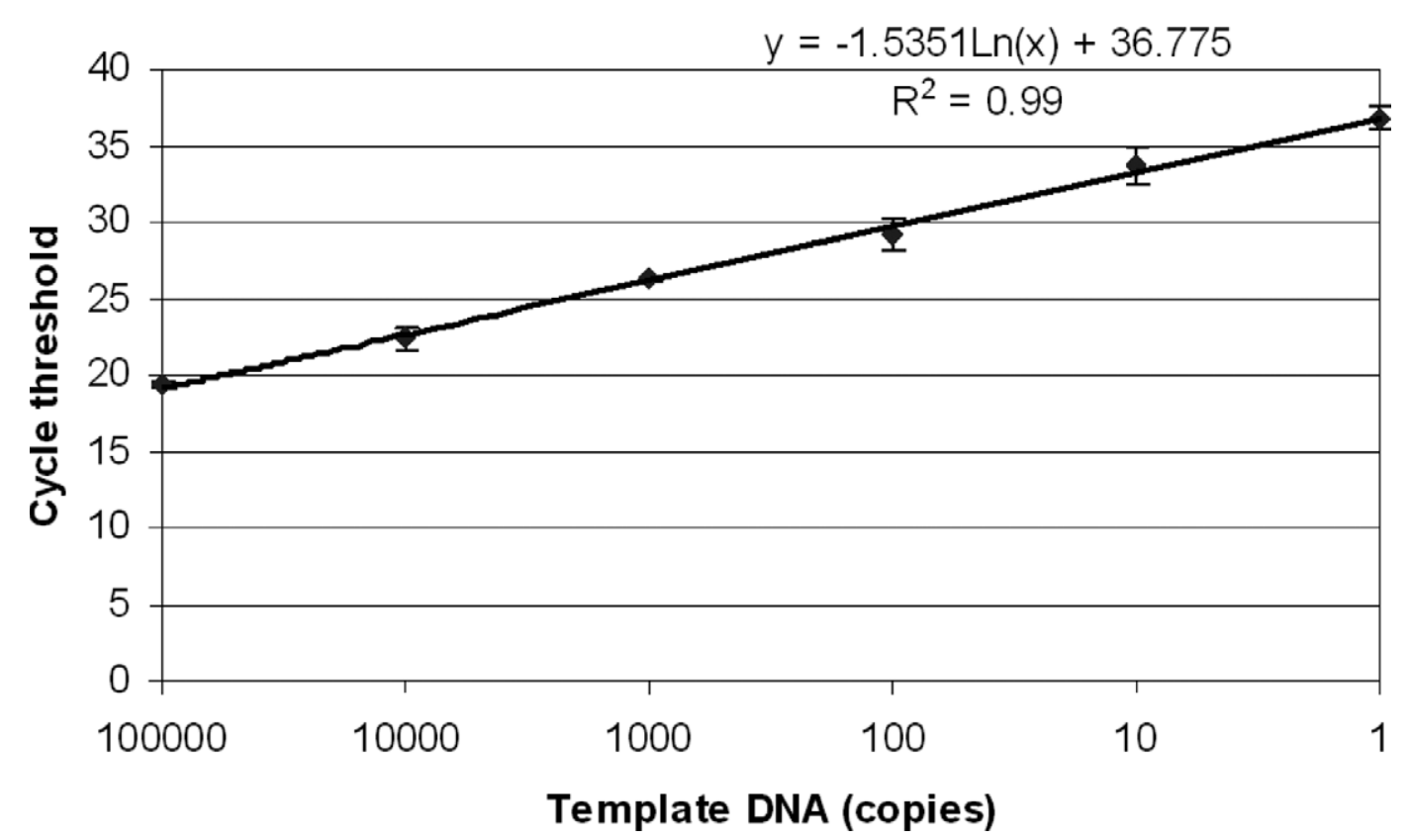

Figure 5. Standard curve of Mycoplasma californicum real-time PCR assay using pIDTSMART-AMP plasmids cloned with the target sequence in $r p o B$ gene of $M$. californicum.

cut-off value gave a detection limit for the $M$. californicum assay of 1 copy of target DNA (Figure 5), whereas the detection limits for $M$. bovis and M. bovigenitalium assays were approximately 10 copies of target DNA (Figures 3 and 4). This choice is consistent with that used by Bustin (2004), who suggested this value to guard against false-positive results due to technical errors that are manifested by weak signals present in negative controls. Using this cut-off value, $4 \mathrm{M}$. bovis isolates that were thought to be of a single species after filter cloning were identified as positive for both $M$. bovis and M. californicum. Those isolates were later confirmed to have both $M$. bovis and M. californicum. Because 16S rRNA gene partial sequencing assay is a qualitative PCR-based technique, only the dominant species in a sample can be detected. Real-time PCR assays can detect and quantify very low amounts of DNA template in a sample even when more than one species is present. For that reason, this real-time PCR assays may be superior to conventional nucleic acid detection techniques when used on mixed infection samples.

\section{CONCLUSIONS}

The real-time PCR assay developed had a lower limit of detection of 10 to $30 \mathrm{cfu} / \mathrm{mL}$ of the tested Mycoplas$m a$ species, approximately 4 to 10 times more sensitive than the detection limits that have been reported for conventional PCR. Moreover, the real-time PCR assay developed can be completed in 20 fewer hours than the conventional PCR procedure. The conventional
PCR-RFLP technique evaluated failed to speciate $M$. bovigenitalium and thus this real-time PCR assay technique is superior in that it correctly speciates the 3 most prevalent Mycoplasma spp. The use of primers and probes that are specific and that have excellent agreement with the $16 \mathrm{~S}$ rRNA gene partial sequencing test for the 3 most prevalent mycoplasma mastitis species suggests its potential to be developed into a routine mastitis diagnostic technique. Tests of the realtime PCR using milk as a diluent indicates that it has promise to be developed further, combining 3 assays in a single, multiplex, real-time test that can be used directly with milk samples.

\section{ACKNOWLEDGMENTS}

The authors acknowledge the excellent technical assistance of Dorothy Newkirk and support from the Agricultural Research Center of Washington State University (Pullman). This study was partially funded by the 2009 Graduate Student and House Officer Research Awards, College of Veterinary Medicine, Washington State University. None of the authors of this paper has a financial or personal relationship with other people or organizations that could inappropriately influence or bias the content of the paper.

\section{REFERENCES}

Altschul, S. F., W. Gish, W. Miller, E. W. Myers, and D. J. Lipman. 1990. Basic local alignment search tool. J. Mol. Biol. 215:403-410. 
Biddle, M. K., L. K. Fox, M. A. Evans, and C. C. Gay. 2005. Pulsedfield gel electrophoresis patterns of Mycoplasma isolates from various body sites in dairy cattle with Mycoplasma mastitis. J. Am. Vet. Med. Assoc. 227:455-459.

Bustin, S. A. 2004. Quantification of nucleic acids by PCR. Pages 3-29 in An A-Z of quantitative PCR. S. A. Bustin, ed. IUL Press, La Jolla, CA.

Cai, H. Y., P. Bell-Rogers, L. Parker, and J. F. Prescott. 2005. Development of a real-time PCR for detection of Mycoplasma bovis in bovine milk and lung samples. J. Vet. Diagn. Invest. 17:537-545.

Fox, L. K., and J. M. Gay. 1993. Contagious mastitis. Pages 475-487. in Update on Bovine Mastitis, Veterinary Clinics of North America: Food Animal Practice. Vol. 9, No. 3. K. L. Anderson, ed. W. B. Saunders Co., Philadelphia, PA.

Fox, L. K., J. H. Kirk, and A. Britten. 2005. Mycoplasma mastitis: A review of transmission and control. J. Vet. Med. B Infect. Dis. Vet. Public Health 52:153-160.

González, R. N., and D. J. Wilson. 2003. Mycoplasmal mastitis in dairy herds. Vet. Clin. North Am. Food Anim. Pract. 19:199-221.

Hale, H. H., C. F. Helmboldt, W. N. Plastridge, and E. F. Stula. 1962. Bovine mastitis caused by a Mycoplasma species. Cornell Vet. $52: 582-591$

Harasawa, R., H. Mizusawa, K. Nozawa, T. Nakagawa, K. Asada, and I. Kato. 1993. Detection and tentative identification of dominant mycoplasma species in cell cultures by restriction analysis of the $16 \mathrm{~S}-23 \mathrm{~S}$ rRNA intergenic spacer regions. Res. Microbiol. 144:489-493.

Hay, R. J., M. L. Macy, and T. R. Chen. 1989. Mycoplasma infection of cultured cells. Nature 339:487-488.

Heid, C. A., J. Stevens, K. J. Livak, and P. M. Williams. 1996. Realtime quantitative PCR. Genome Res. 6:986-994.

Hirose, K., H. Kawasaki, K. Kotani, A. Tanaka, K. Abiko, and H. Ogawa. 2001. Detection of Mycoplasma in mastitic milk by PCR analysis and culture method. J. Vet. Med. Sci. 63:691-693.

Hogan, J. S., R. N. Gonzalez, R. J. Harmon, S. C. Nickerson, S. P. Oliver, J. W. Pankey, and K. L. Smith. 1999. Laboratory and Field Handbook on Bovine Mastitis. National Mastitis Council Inc., Madison, WI.

Infante, F., F. Infante Jr., and G. H. Flores-Gutiérrez. 2002. Improved immunobinding test using monoclonal antibodies for detection of Mycoplasma bovis in milk. Can. J. Vet. Res. 66:282-284.

Infante Martinez, F., D. E. Jasper, J. L. Stott, J. S. Cullor, and J. D. Dellinger. 1990. Immunobinding assay for detection of Mycoplasma bovis in milk. Can. J. Vet. Res. 54:251-255.

Jackson, G., and E. A. Boughton. 1991. A mild outbreak of bovine mastitis associated with Mycoplasma bovigenitalium. Vet. Rec. 129:444-446.
Jasper, D. E. 1979. Bovine mycoplasmal mastitis. J. Am. Vet. Med. Assoc. 175:1072-1074.

Jasper, D. E. 1980. Prevalence of mycoplasma mastitis in the Western states. Calif. Vet. 4:24-26.

Jurmanová, K., M. Hájková, and J. Védova. 1983. Further evidence of the involvement of Mycoplasma californicum in bovine mastitis in Europe. Vet. Rec. 112:608.

Kirk, J. H., K. Glenn, L. Ruiz, and E. Smith. 1997. Epidemiologic analysis of Mycoplasma spp. isolated from bulk-tank milk samples obtained from dairy herds that were members of a milk cooperative. J. Am. Vet. Med. Assoc. 211:1036-1038.

Kirk, J. H., and L. H. Lauerrman. 1994. Mycoplasma mastitis in dairy cows. Compend. Contin. Educ. Pract. Vet. 16:541-558.

Leutenegger, C. M. 2001. The real-time TaqMan PCR and applications in veterinary medicine. Vet. Sci. Tomorrow 1:1-15.

Mackie, D. P., H. J. Ball, and E. F. Logan. 1986. Mycoplasma californicum mastitis in the dry dairy cow. Vet. Rec. 119:350-351.

Nicholas, R. N., R. Ayling, and L. McAuliffe. 2007. Mycoplasma mastitis. Vet. Rec. 160:382.

Pitcher, D. G., N. A. Saunders, and R. J. Owen. 1989. Rapid extraction of bacterial genomic DNA with guanidine thiocyanate. Lett. Appl. Microbiol. 8:151-156.

Pinnow, C. C., J. A. Butler, K. Sachse, H. Hotzel, L. L. Timms, and R. F. Rosenbusch. 2001. Detection of Mycoplasma bovis in preservative-treated field milk samples. J. Dairy Sci. 84:1640-1645.

Rossetti, B. C., J. Frey, and P. Pilo. 2010. Direct detection of Mycoplasma bovis in milk and tissue samples by real-time PCR. Mol. Cell. Probes 24:321-323.

Sachse, K., H. S. H. Salam, R. Diller, E. Schubert, B. Hoffmann, and H. Hotzel. 2010. Use of a novel real-time PCR technique to monitor and quantitate Mycoplasma bovis infection in cattle herds with mastitis and respiratory disease. Vet. J. 186:299-303.

Stakenborg, T., J. Vicca, P. Butaye, D. Maes, T. De Baere, R. Verhelst, J. Peeters, A. de Kruif, F. Haesebrouck, and M. Vaneechoutte. 2005. Evaluation of amplified rDNA restriction analysis (ARDRA) for the identification of Mycoplasma species. BMC Infect. Dis. $5: 46$.

Tang, J., M. Hu, S. Lee, and R. Roblin. 2000. A polymerase chain reaction based method for detecting Mycoplasma/Acholeplasma contaminants in cell culture. J. Microbiol. Methods 39:121-126.

Tully, J. G. 1983. Tests for digitonin sensitivity and sterol requirement. Pages 355-362 in Methods in Mycoplasmology. I. J. G. Tully and S. Razin, ed. Academic Press, New York, NY.

USDA Animal and Plant Health Inspection Service. 2008. Prevalence of Contagious Mastitis Pathogens on U.S. Dairy Operations, 2007. Information Sheet. N533.1008. 